\title{
Canadian health care slurs dismissed as "rhetoric"
}

A s a dual citizen of Canada and the United States, Sister Nuala Kenny, professor of bioethics at Dalhousie University in Halifax, Nova Scotia, is "profoundly embarrassed" by the way Canadians have been relentlessly slagged during America's debate over reform of its health care system.

American Medical Association President Dr. James Rohack, meanwhile, is almost apologetic.

During a summer of town hall debates on US President Barack Obama's proposed overhaul of the American system, the Canadian health care system has become synonymous with eugenics, euthanasia, "communist rationing," and even death-list panels wherein doctors sit as omnipotent gods, indifferently deigning to declare who lives and who dies. The polemic has certainly not gone unnoticed, as was evident during corridor chatter at the Canadian Medical Association's 142nd annual general meeting held in Saskatoon, Saskatchewan, Aug. 17-19.

Casting Canada as the sort of country that routinely culls the defects from the herd is nothing short of an affront to all of its citizens, Kenny says. "It's evil or it's stupid."

"It's appalling," adds Liberal Member of Parliament (St. Paul's) Dr. Carolyn Bennett.

Rohack, though, dismisses the slurs as mere "rhetoric" in a heated debate about the role of government in social programs, in an equally overheated media environment in which "horror stories tend to get more press than the millions of Canadian citizens who are getting good quality care every day."

"There are a lot of misperceptions," Rohack says, adding that many Canadian physicians have bluntly informed him that they resent being depicted as "unfeeling and uncaring."

"It's unfortunate because it has painted a vision in many Americans that Canadians are not getting good care and that's not true," he says. Moreover, Canada has managed to achieve univer-

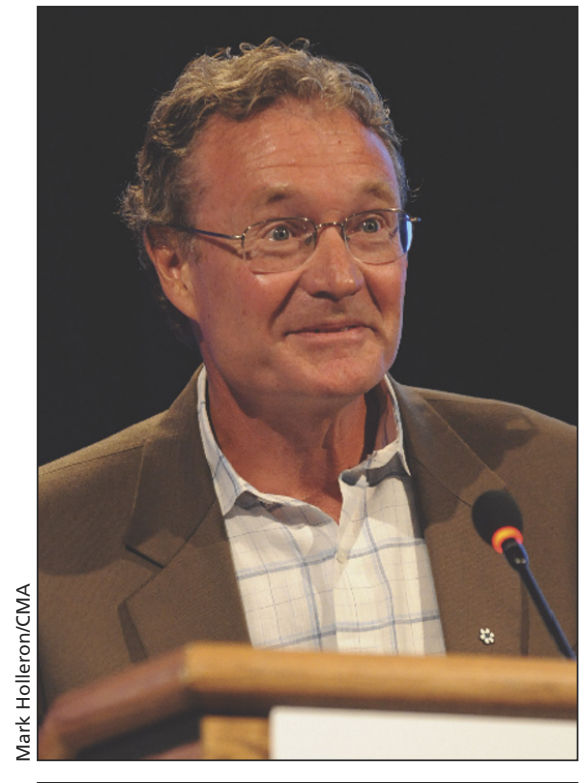

Health care is "very much like religion or politics," says Dr. Jeff Turnbull, president-elect of the Canadian Medical Association.

sal health coverage while "we have a problem because $15 \%$ of our people don't have health insurance and they access health care only through the emergency room and we know that they live sicker and they die younger.'

Kenny can't help but surmise that Canada's critics are speaking on behalf of vested interests. "There have got to be tons of shills at these meetings. These cannot be ordinary Americans. They can't be real."

\section{Historic differences}

Yet, the rhetoric is entirely in keeping with historic differences in the character of each country's population, differences that can be traced back to the American revolution, says Kenny, who was born in New York City and moved to Canada when she was 18 .

America was founded by people who rejected the notion that government has a role to play in people's lives, while the Loyalists, "who had a different sense of community, as compared and contrasted to individual freedom, fled to Canada."
"Watch the rhetoric," adds Kenny, who was a member of the National Forum on Health, an advisory body that was established by former Prime Minister Jean Chrétien in October 1994 to recommend ways of improving the health care system. "It's not rooted in what kind of health care system would best serve the American people. It's an instant knee-jerk reaction of Americans: anything that the government does, it does inefficiently. Anything that the market does, it does well. The Canadian conception is clearly different. The government has an absolute, distinct role, as it is understood in most Western democracies, to promote the common good."

"In Canada, health care is a public good. In the US, it's a market good," she adds.

CMA President-Elect Dr. Jeff Turnbull says the rhetoric is also rooted in differing notions of "health equity" and civic responsibility.

"Health care is something like religion and politics," he says. "It's very much personal beliefs about how you view your person. And if you [have] a perspective that might have some suggestion of government influence, despite the fact it may [be] cheaper and more effective, the rhetoric will be jumped up to a new level. Evidence will not be the deciding factor."

Kenny laments that the real consequence of such a polemical debate will be most heavily felt by average Americans, particularly in an economy in which job losses mean fewer and fewer people are covered by insurance.

And the antigovernment sentiment is potentially disastrous in something like a flu pandemic, she adds. "You cannot protect yourself without [considering] the common good, the sum total of social conditions that allow for safety, because we're so interdependent. The idea that you can live in a bubble, and bring your whole family into it, is ludicrous."

Yet, perversely, there may be a beneficial impact in Canada, Kenny says. 
Canadians may be lulled out of complacency about the merits of their health care system and then support "actions that need to be taken to improve it. The status quo is not what any of us wants, but going private-forprofit gives you this debacle."

Outgoing CMA President Dr. Robert Ouellet also hopes the slurs serve as an impetus for systemic reform. "The influence from the US to Canada is huge. The media are everywhere."

Canadian Doctors for Medicare Chair Dr. Danielle Martin frets about exactly that kind of ripple effect. "If we open up to private-for-profit delivery of health care services in Canada, it's not the Dutch companies that are going to be coming here to try to set up shop, it's not the French long-term care consortia that are going to be coming into Canada trying to get contracts to take care of our elderly. We can say that we're not interested in American model of health care. But that doesn't mean that the American model of health care isn't interested in us." - Wayne Kondro, CMAJ

DOI:10.1503/cmaj.109-3027 